\title{
Synthesis and Polymerization of Novel Vinyl Monomers having Intramolecular Urethane Bond and Glycerin Group
}

\author{
Eui-Chul KAng ${ }^{\dagger}$ Atsuhiko Ogura, Takashi IwATA, \\ Shingo KATAOKA, and Yutaka MARUHASHI \\ Tsukuba Corporate Research Laboratory, NOF Corporation, \\ 5-10 Tokodai, Tsukuba 300-2635, Japan
}

(Received July 20, 2006; Accepted August 17, 2006; Published October 4, 2006)

\begin{abstract}
KEY WORDS Glycerol / Isopropylidene Glycerol / 2-Methacryloyloxyethyl Isocyanate / Isopropylideneglyceryl- $N$-(2-methacryloyloxyethyl)urethane / Glyceryl- $N$-(2-methacryloyloxyethyl)urethane /

[doi:10.1295/polymj.PJ2006080]
\end{abstract}

Water-soluble polymers have been widely used in many industrial fields, such as adhesives, pulp, textiles, foods, drugs, cosmetics, paints, and coatings. ${ }^{1}$ There are classified as three groups according to their origin, i.e., natural (protein, cellulose, starch, etc.), synthetic (polyvinylalcohol, polyacrylamide, polyvinylpyrrolidone, etc.), and semi-synthetic (carboxylmethyl cellulose, methylcellulose, etc.) formed by modifying natural materials to produce forms with more desirable properties. We have also produced several water-soluble monomers and polymers, for example, 2-(methacryloyloxy)ethyl phosphorylcholine (MPC), glycerol monomethacrylate (GLM), polyalkyleneglycol mono(meth)acrylates and its polymers, and so forth. ${ }^{2-4}$

2-Methacryloyloxyethyl isocyanate (MOI) is a difunctional monomer with both a reactive isocyanate group and a vinyl polymerizable double bond. ${ }^{5}$ MOI is also useful for preparation of macromonomer. Many kinds of MOI derivatives have been synthesized from several alcohol and amine compounds, and their polymerization and physicochemical properties were also studied ${ }^{6-10}$ Recently, many research groups have been extensively studied the preparation of organic/ inorganic polymer hybrid using the sol-gel technique. ${ }^{11-14}$ Generally, the polymer hybrid prepared by utilizing physical interactions such as hydrogen bonding, ionic and aromatic $\pi-\pi$ interactions. From the viewpoint of the formation of hydrogen bonding both polymer and inorganic metal oxide such as silica, titania and alumina plates, we synthesized the novel vinyl monomers with intramolecular urethane bond and two hydroxyl groups. In this article, the synthesis, polymerization and its properties of the novel vinyl monomers with urethane bond and glycerin group are described.

\section{EXPERIMENTAL}

\section{Materials}

2-Methacryloyloxyethyl isocyanate was purchased from Showa Denko Co. Ltd., Tokyo, Japan. Triethylamine (TEA) and azobisisobutyronitrile (AIBN) were purchased from Wako Pure Chemicals Co. Tokyo, Japan. Isopropylidene glycerol (IPG) was prepared from the acid-catalyzed reaction of glycerol and acetone according to the reported method. ${ }^{15}$ All other solvents and chemicals were used without further purification.

Isopropylideneglyceryl-N-(2-methacryloyloxyethyl)urethane (IPGMOU)

To the mixture of IPG $(13.2 \mathrm{~g}, 0.1 \mathrm{~mol})$ and TEA $(1.0 \mathrm{~mL})$ was added dropwise 2-methacryloyloxyethyl isocyanate $(15.5 \mathrm{~g}, 0.1 \mathrm{~mol})$ with stirring at room temperature. After the addition was completed, stirring was continued at $50^{\circ} \mathrm{C}$ for $6 \mathrm{~h}$. TEA was removed from the reaction mixture under reduced pressure, and the reaction mixture was washed twice with distilled water and dried with phosphorus pentoxide. The product was further purified by recrystallization from hexane and isopropyl alcohol. Subsequent drying in vacuum for $24 \mathrm{~h}$ at $40^{\circ} \mathrm{C}$ yielded $24.2 \mathrm{~g}(84.3 \%)$ of white solid: purity $99.5 \%$ (by GC); $\mathrm{mp} 44.4^{\circ} \mathrm{C} ; \mathrm{n}_{\mathrm{D}}{ }^{50} 1.4556$; IR (KBr) $3360(\mathrm{~N}-\mathrm{H}), 1716(\mathrm{C}=\mathrm{O}), 1380 \mathrm{~cm}^{-1}$ $\left(\mathrm{C}\left(\mathrm{CH}_{3}\right)_{2}\right) ;{ }^{1} \mathrm{H} \mathrm{NMR}\left(\mathrm{CDCl}_{3}\right) \delta=6.09(\mathrm{~s}, 1 \mathrm{H}, \mathrm{HC}=\mathrm{C}$, trans), $5.58(\mathrm{~s}, 1 \mathrm{H}, \mathrm{HC}=\mathrm{C}$, cis), $5.04(\mathrm{br}, 1 \mathrm{H}, \mathrm{NH}-$ COO), 3.66-4.34 (m, 7H, $\mathrm{CH}_{2} \mathrm{CHCH}_{2}, \mathrm{COOCH}_{2}$ ),

${ }^{\dagger}$ To whom correspondence should be addressed (Tel: +81-29-847-8894, Fax: +81-29-847-8862, E-mail: euichul_kang@ @of.co.jp). 
3.48 (q, 2H, $\left.\mathrm{CH}_{2} \mathrm{NH}\right), 1.93$ (s, 3H, $\left.=\mathrm{CCH}_{3}\right), 1.42$, 1.35 (two s, 6H, C( $\left.\left(\mathrm{CH}_{3}\right)_{2}\right)$; HRMS $\left(\mathrm{MH}^{+}\right.$) calcd for $\mathrm{C}_{13} \mathrm{H}_{22} \mathrm{O}_{6} \mathrm{~N}, 288.1471$, found, 288.1447.

\section{Glyceryl-N-(2-methacryloyloxyethyl)urethane (GLY- $M O U)$}

To the solution of IPGMOU $(10 \mathrm{~g})$ in methanol $(40 \mathrm{~mL})$ was added aqueous $4 \mathrm{~N} \mathrm{HCl}(1.0 \mathrm{~mL})$, and the solution was stirred at room temperature for $6 \mathrm{~h}$. After the deprotection was completed, methanol was evaporated under reduced pressure. Subsequent drying with phosphorus pentoxide in vacuum at $40{ }^{\circ} \mathrm{C}$ yielded as a colorless viscous liquid. The yield of product was quantitative $(8.55 \mathrm{~g})$ : purity $99.5 \%$ (by HPLC); $\mathrm{n}_{\mathrm{D}}{ }^{20}$ 1.4800; IR $\left(\mathrm{CH}_{3} \mathrm{OH}\right) 3370(\mathrm{O}-\mathrm{H}, \mathrm{N}-\mathrm{H}), 1701$ $\mathrm{cm}^{-1}(\mathrm{C}=\mathrm{O}) ;{ }^{1} \mathrm{H}$ NMR $\left(\mathrm{D}_{2} \mathrm{O}\right) \delta=6.03(\mathrm{~s}, 1 \mathrm{H}, \mathrm{HC}=$ $\mathrm{C}$, trans), $5.62(\mathrm{~s}, 1 \mathrm{H}, \mathrm{HC}=\mathrm{C}$, cis), 3.45-4.18 $(\mathrm{m}, 7 \mathrm{H}$, $\mathrm{COOCH}_{2}, \mathrm{CH}_{2} \mathrm{CHCH}_{2}$ ), 3.37 (q, 2H, $\mathrm{CH}_{2} \mathrm{NH}$ ), 1.82 $\left(\mathrm{s}, 3 \mathrm{H},=\mathrm{CCH}_{3}\right)$; HRMS $\left(\mathrm{MH}^{+}\right)$calcd for $\mathrm{C}_{10} \mathrm{H}_{18^{-}}$ $\mathrm{O}_{6} \mathrm{~N}, 248.1131$, found, 248.1134 .

\section{Polymerization of IPGMOU}

$10.0 \mathrm{~g}$ of IPGMOU and $0.05 \mathrm{~g}$ of AIBN as a radical initiator were dissolved in $50 \mathrm{~mL}$ of methanol. After argon gas was bubbled into the solution to eliminate oxygen, the tube was sealed. Then the polymerization tube was shaken at $60^{\circ} \mathrm{C}$ for $24 \mathrm{~h}$. After the reaction solution cooled down, the resulting crude polymer was precipitated, and separated by centrifugation. The crude polymer was redispersed in hot methanol, and then cooled down and centrifuged again. The purification was repeated two times. The resulting polymer was collected and dried in vacuum for $24 \mathrm{~h}$ at $50^{\circ} \mathrm{C}$, to give a white solid. The polymer weighed $8.3 \mathrm{~g}\left(83 \%\right.$ yield), and had $M_{\mathrm{w}}$ of 401,000 and $M_{\mathrm{w}} / M_{\mathrm{n}}$ of 2.70 .

${ }^{1} \mathrm{H}$ NMR $\left(\mathrm{CDCl}_{3}\right) \delta=5.81(\mathrm{br}, 1 \mathrm{H}, \mathrm{NHCOO})$, 3.70-4.30 (m, 7H, $\left.\mathrm{CH}_{2} \mathrm{CHCH}_{2}, \mathrm{COOCH}_{2}\right), 3.45$ (br s, 2H, $\mathrm{CH}_{2} \mathrm{NH}$ ), 1.78 (br s, 2H, $\mathrm{CCH}_{2}$ ) 1.41, 1.34 (two s, 6H, $\mathrm{C}\left(\mathrm{CH}_{3}\right)_{2}$ ), 0.87-1.03 (br s, 3H, $=\mathrm{CCH}_{3}$ ).

\section{Deprotection of Poly(IPGMOU)}

To the solution of poly(IPGMOU) $(0.5 \mathrm{~g})$ in $\mathrm{MeOH} /$ water ( $1 / 1$ by vol., $5 \mathrm{~mL}$ ) was added aqueous $4 \mathrm{~N} \mathrm{HCl}(0.1 \mathrm{~mL})$, and the solution was stirred at room temperature for $24 \mathrm{~h}$. The solution gradually cleared as the reaction progressed. The resulting deprotected polymer was precipitated into an excess amount of methanol. The resulting polymer was dried in vaccum for $24 \mathrm{~h}$ at $50^{\circ} \mathrm{C}$, yielded a white solid. The yield of product was quantitative.

${ }^{1} \mathrm{H}$ NMR $\left(\mathrm{D}_{2} \mathrm{O}\right) \delta=3.43-4.01\left(\mathrm{~m}, 7 \mathrm{H}, \mathrm{CH}_{2} \mathrm{CH}-\right.$ $\mathrm{CH}_{2}, \mathrm{COOCH}_{2}$ ), 3.32 (br s, $2 \mathrm{H}, \mathrm{CH}_{2} \mathrm{NH}$ ), 1.78 (br s, $2 \mathrm{H}, \mathrm{CCH}_{2}$ ), 0.71, 0.89 (br two s, $3 \mathrm{H},=\mathrm{CCH}_{3}$ ).

\section{Polymerization of GLYMOU}

$10.0 \mathrm{~g}$ of GLYMOU and $0.05 \mathrm{~g}$ of AIBN as a radical initiator were dissolved in $50 \mathrm{~mL}$ of methanol/water (4/1 by vol.). After argon gas was bubbled into the solution to eliminate oxygen, the tube was sealed. Then the polymerization tube was shaken at $60^{\circ} \mathrm{C}$ for $24 \mathrm{~h}$. The resulting crude polymer was precipitated into an excess amount of methanol. The resulting polymer was collected and dried in vacuum for $24 \mathrm{~h}$ at $50{ }^{\circ} \mathrm{C}$. The polymer weighed $8.7 \mathrm{~g}$ ( $87 \%$ yield), and had $M_{\mathrm{w}}$ of 748,000 and $M_{\mathrm{w}} / M_{\mathrm{n}}$ of 2.46 .

${ }^{1} \mathrm{H}$ NMR $\left(\mathrm{D}_{2} \mathrm{O}\right) \delta=3.43-4.01\left(\mathrm{~m}, 7 \mathrm{H}, \mathrm{CH}_{2} \mathrm{CH}-\right.$ $\mathrm{CH}_{2}, \mathrm{COOCH}_{2}$ ), 3.32 (br s, 2H, $\mathrm{CH}_{2} \mathrm{NH}$ ), 1.78 (br s, $2 \mathrm{H}, \mathrm{CCH}_{2}$ ), 0.71, 0.89 (br two s, $3 \mathrm{H},=\mathrm{CCH}_{3}$ ).

\section{Measurements}

IR spectra were recorded by using a Jasco FT/ IR-7300 Fourier transform infrared spectrometer. ${ }^{1} \mathrm{H}$ NMR spectra were carried out in $\mathrm{D}_{2} \mathrm{O}$ (deuterated water) and $\mathrm{CDCl}_{3}$ (deuterated chloroform) by using a JEOL JNM-EX270 spectrometer. The chemical shifts were recorded as parts per million ( $\mathrm{ppm}$ ) with a reference to residual solvent resonance. High-resolution mass spectra (HRMS) were obtained by using a JEOL JMS-700 MStation. The molecular weight was determined by gel permeation chromatography (GPC) on a TOSOH-HPLC apparatus (PL Laboratories MixedB column) with polystyrene as a standard in DMF containing $10 \mathrm{mM} \mathrm{LiCl}$ as an eluent at $40^{\circ} \mathrm{C}$. The thermal properties were measured by differential scanning calorimetry (DSC, Seiko DSC-210) and thermogravimetry (TG, Seiko thermal analyzer TG-220) in nitrogen.

\section{RESULTS AND DISCUSSION}

IPGMOU monomer synthesized with IPG and MOI, and GLYMOU monomer with two hydroxyl groups synthesized by the deprotection of isopropylidene group in IPGMOU monomer. GLYMOU polymer synthesized by the free radical polymerization of GLYMOU monomer and also synthesized by the deprotection of IPGMOU polymer (Scheme 1).

The IR spectra of IPGMOU and GLYMOU polymers are shown in Figure 1. The absorption peaks characteristic of IPGMOU polymer appeared at $1726 \mathrm{~cm}^{-1}$ due to $\mathrm{C}=\mathrm{O}$ stretching of the ester group and at $3350 \mathrm{~cm}^{-1}$ derived from $\mathrm{N}-\mathrm{H}$ stretching of the urethane group. The absorption bands at $1370 \mathrm{~cm}^{-1}$ $\left(\mathrm{C}\left(\mathrm{CH}_{3}\right)_{2}\right.$ stretching $)$ and $840 \mathrm{~cm}^{-1}(\mathrm{C}-\mathrm{O}$ stretching of the cyclic ketal structure) are attributed to the existence of isopropylidene group. In the GLYMOU polymer, a very strong $\mathrm{O}-\mathrm{H}$ stretching band due to the hydroxyl group appeared at $3370 \mathrm{~cm}^{-1}$, and the absorption band due to the cyclic ketal structure of 

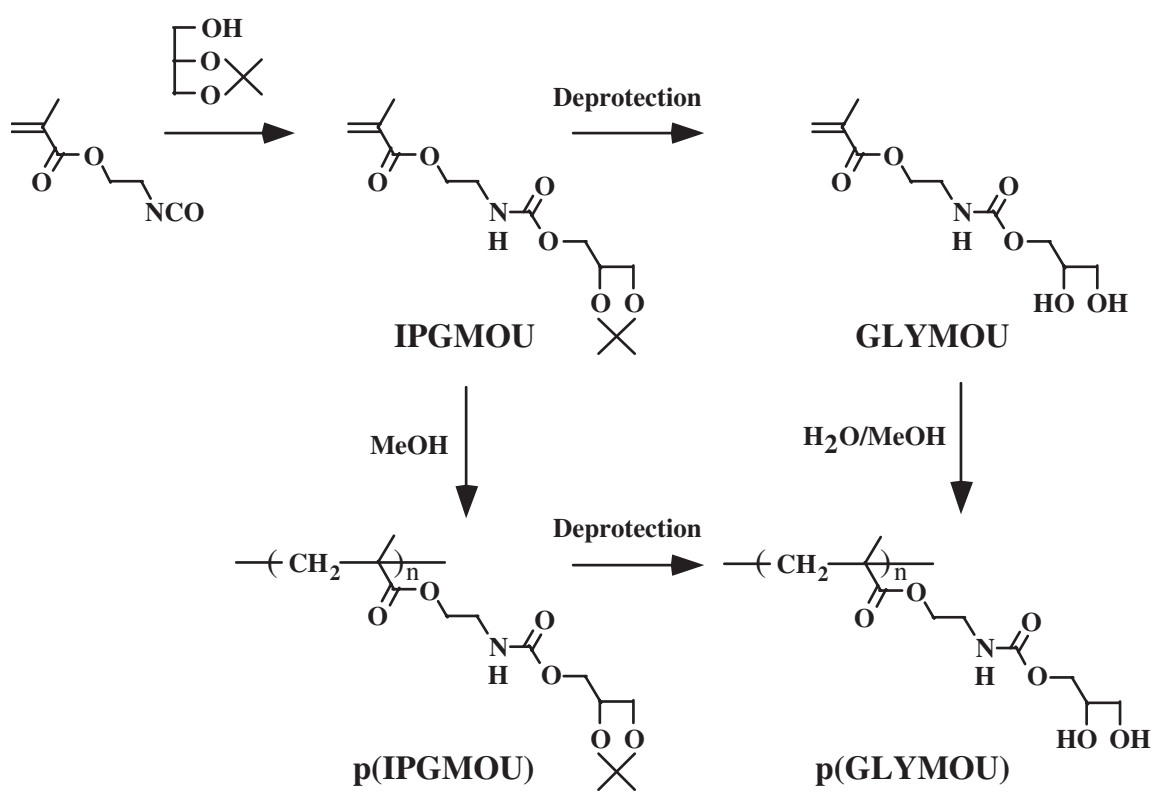

Scheme 1. Synthetic route of IPGMOU and GLYMOU monomers, and their polymers.

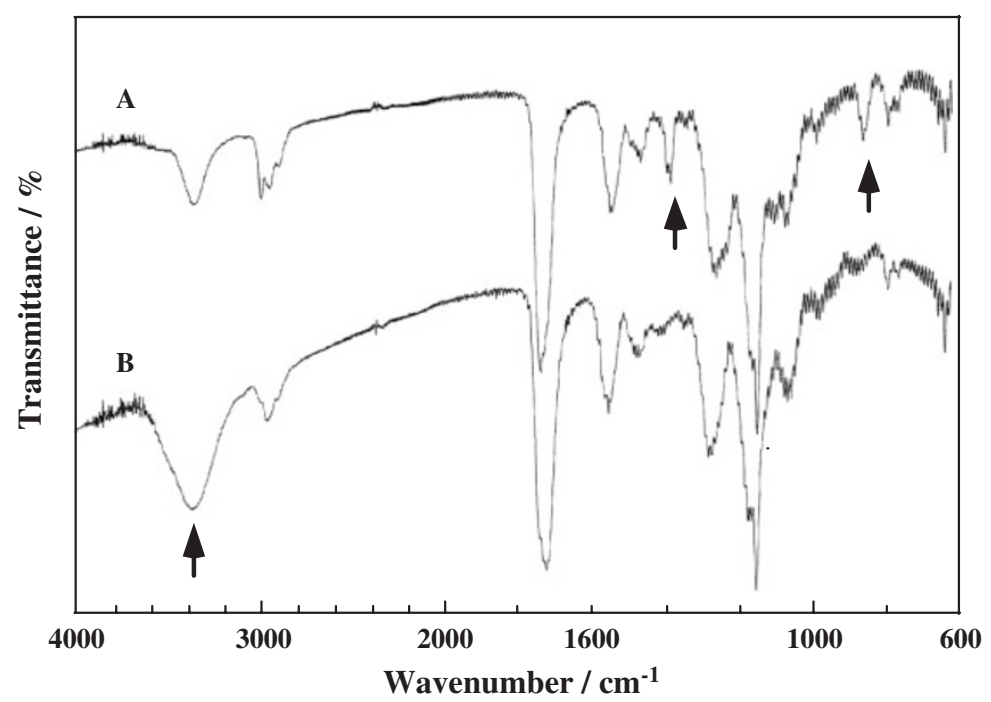

Figure 1. IR spectra of (A) IPGMOU and (B) GLYMOU polymers.

the isopropylidene group at $1370 \mathrm{~cm}^{-1}$ and $840 \mathrm{~cm}^{-1}$ did not exhibit. The peak of $\mathrm{C}=\mathrm{O}$ stretching absorptions shifted from $1726 \mathrm{~cm}^{-1}$ (in IPGMOU polymer) to $1705 \mathrm{~cm}^{-1}$ and became slightly broad, suggesting that hydrogen bonding between carbonyl and hydroxyl group in the GLYMOU polymer chain caused a decrease in the carbonyl frequency.

The main signals in the ${ }^{1} \mathrm{H}$ NMR spectra of IPGMOU and GLYMOU polymers are shown in Figure 2. The ${ }^{1} \mathrm{H}$ NMR spectrum of IPGMOU polymer showed two peaks at 1.3 and $1.4 \mathrm{ppm}$ due to the methyl group of the isopropylidene group. The ${ }^{1} \mathrm{H}$ NMR spectrum of GLYMOU polymer disappeared two peaks at 1.3 and $1.4 \mathrm{ppm}$ due to isopropylidene group.

The IR and ${ }^{1} \mathrm{H}$ NMR spectra of GLYMOU polymer prepared by the deprotection of IPGMOU polymer also coincided with those of GLYMOU polymer directly prepared from GLYMOU monomer.

The solubility of IPGMOU and GLYMOU monomers, and their polymers in different organic solvents was investigated and summarized in Table I. IPGMOU monomer was soluble in almost organic solvents except for water and hexane. The solubility behavior of IPGMOU polymer was similar to that of monomer. GLYMOU monomer having two hydroxyl groups was soluble in almost polar solvents, but insoluble in non-polar solvents such as THF, EtOAc, hexane, and so forth. On the other hand, GLYMOU polymer was soluble in water and aprotic polar solvents such as DMF and DMSO, but insoluble in almost organic solvents. 


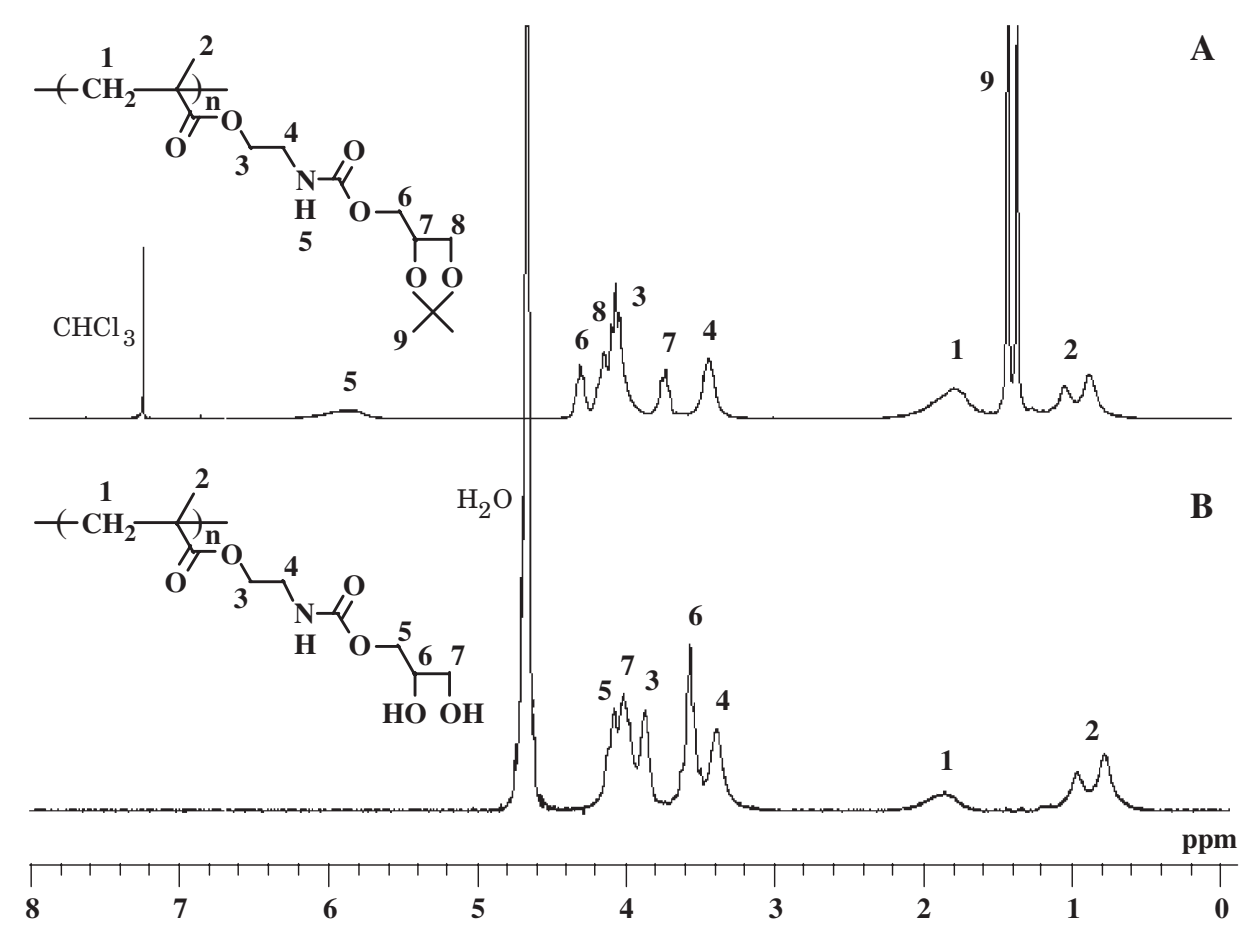

Figure 2. ${ }^{1} \mathrm{H}$ NMR spectra of (A) IPGMOU and (B) GLYMOU polymers in $\mathrm{CD}_{3} \mathrm{OD}$ and $\mathrm{D}_{2} \mathrm{O}$ at $25^{\circ} \mathrm{C}$.

Table I. Solubilities of IPGMOU and GLYMOU monomers, and their homopolymers

\begin{tabular}{lccccc}
\hline & \multicolumn{2}{c}{ IPGMOU } & & \multicolumn{2}{c}{ GLYMOU } \\
\cline { 2 - 3 } \cline { 5 - 6 } \cline { 5 - 6 } & monomer & polymer & & monomer & polymer \\
\hline $\mathrm{H}_{2} \mathrm{O}$ & $\mathrm{I}$ & $\mathrm{I}$ & & $\mathrm{S}$ & $\mathrm{S}$ \\
$\mathrm{MeOH}$ & $\mathrm{S}$ & $\mathrm{SH}$ & & $\mathrm{S}$ & $\mathrm{I}$ \\
$\mathrm{EtOH}$ & $\mathrm{S}$ & $\mathrm{SH}$ & & $\mathrm{S}$ & $\mathrm{I}$ \\
$i-\mathrm{PrOH}$ & $\mathrm{S}$ & $\mathrm{SW}$ & & $\mathrm{S}$ & $\mathrm{I}$ \\
$\mathrm{MeCN}$ & $\mathrm{S}$ & $\mathrm{S}$ & & $\mathrm{S}$ & $\mathrm{I}$ \\
Acetone & $\mathrm{S}$ & $\mathrm{S}$ & & $\mathrm{S}$ & $\mathrm{I}$ \\
DMSO & $\mathrm{S}$ & $\mathrm{S}$ & & $\mathrm{S}$ & $\mathrm{S}$ \\
DMF & $\mathrm{S}$ & $\mathrm{S}$ & & $\mathrm{S}$ & $\mathrm{S}$ \\
THF & $\mathrm{S}$ & $\mathrm{S}$ & & $\mathrm{I}$ & $\mathrm{I}$ \\
EtOAc & $\mathrm{S}$ & $\mathrm{S}$ & & $\mathrm{I}$ & $\mathrm{I}$ \\
Hexane & $\mathrm{I}$ & $\mathrm{I}$ & & $\mathrm{I}$ & $\mathrm{I}$ \\
\hline
\end{tabular}

Solubility was measured in $20 \mathrm{wt} \%$ solution at $25^{\circ} \mathrm{C}$; S, soluble; SH, soluble at heating; SW, swelling; I, insoluble.

The thermal properties of IPGMOU and GLYMOU polymers were measured by TGA, DTA, and DSC in nitrogen. Figure 3 showed TG/DTA curves of IPGMOU and GLYMOU polymers. The $10 \mathrm{wt} \%$ weight-loss degradation temperature of IPGMOU polymer (about $282^{\circ} \mathrm{C}$ ) was relatively higher than that of GLYMOU polymer (about $240^{\circ} \mathrm{C}$ ). The degradation in IPGMOU polymer at $280^{\circ} \mathrm{C}$ is due to that of the urethane bond in the side chain. On the other hand, the TG curve of GLYMOU polymer showed two-step degradation behavior. The first weight-loss step from 215 to $300{ }^{\circ} \mathrm{C}$ suggests degradation of the urethane bond and glycerin moiety in GLYMOU polymer and

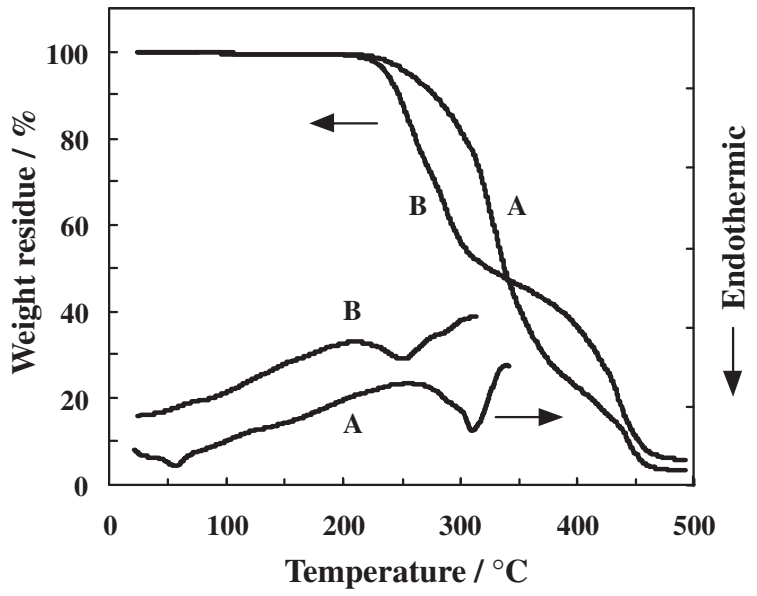

Figure 3. TG/DTA curves of (A) IPGMOU and (B) GLYMOU polymers measured at a heating rate of $10^{\circ} \mathrm{C} / \mathrm{min}$ in nitrogen.

because the weight-loss value (about $48 \%$ ) is almost consistent with the weight composition of urethane bond and glycerin moiety in GLYMOU polymer. An endothermic peak derived from the DTA curve was observed at 280 (degradation of urethane bond) and $250^{\circ} \mathrm{C}$ (degradation of glycerin moiety). Such a thermal degradation of GLYMOU polymer at relatively low temperature may be attributed to markedly promote the degradation reaction of the glycerin moiety in GLYMOU polymer.

Figure 4 showed DSC curves of IPGMOU and GLYMOU polymers. The glass transition temperatures $\left(T_{\mathrm{g}}\right)$ of IPGMOU and GLYMOU polymers were 


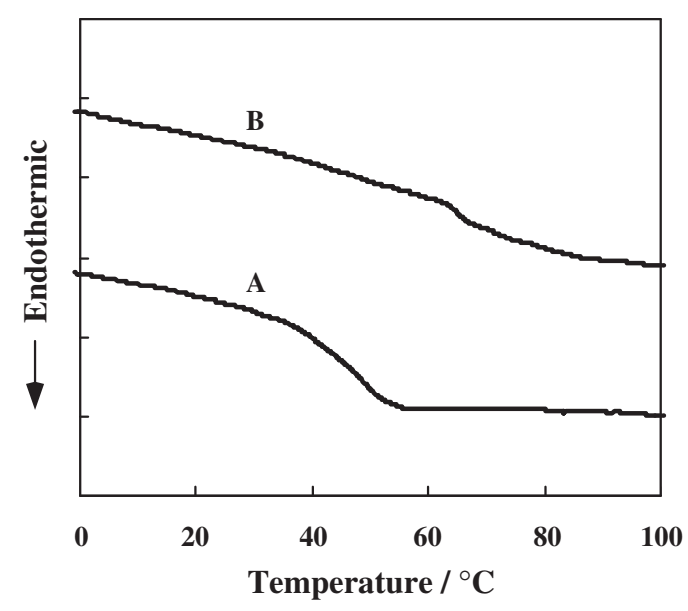

Figure 4. DSC curves of (A) IPGMOU and (B) GLYMOU polymers obtained on heating.

43 and $63{ }^{\circ} \mathrm{C}$, respectively. $T_{\mathrm{g}}$ of GLYMOU polymer increased over $20^{\circ} \mathrm{C}$ compared to that of IPGMOU polymer, probably because of the hydrogen bonding of hydroxyl groups.

In summary, the novel vinyl monomers with urethane bond and glycerin group, IPGMOU and GLYMOU, were obtained by the reaction of isopropylidene glycerol and MOI, with the following deprotection. The thermal stability of GLYMOU polymer with hydroxyl groups was found to be much lower than that of IPGMOU polymer protected isopropylidene groups. Further studies concerning the reactivity ratios in the copolymerization of IPGMOU and
GLYMOU monomers with other comonomers and their thermal and mechanical properties are now in progress.

\section{REFERENCES}

1. P. Molyneux, "Water-soluble Synthetic Polymers: Properties and Behavior," CRC press, Florida, 1991.

2. K. Ishihara, R. Aragaki, T. Ueda, A. Watanaba, and N. Nakabayashi, J. Biomed. Mater. Res., 24, 1069 (1990).

3. M.-Q. Chen, T. Serizawa, A. Kishida, and M. Akashi, J. Polym. Sci., Part A: Polym. Chem., 37, 2155 (1999).

4. http: www.nof.co.jp

5. M. R. Thomas, J. Coat. Technol., 55, 55 (1983).

6. H. Kamogawa, H. Kohno, and R. Kitagawa, J. Polym. Sci., Part A: Polym. Chem., 27, 487 (1989).

7. C. H. Bamford, K. G. Al-Lamee, I. P. Middleton, J. Paprotny, and R. Carr, Bull. Soc. Chim. Belg., 99, 919 (1990).

8. F. Ignatious, A. Sein, I. Cabasso, and J. Smid, J. Polym. Sci., Part A: Polym. Chem., 31, 239 (1993).

9. C. C. Chappelow, T. J. Byerley, C. S. Pinzino, F. Millich, and J. D. Eick, J. Dent. Res., 75, 761 (1996).

10. Y.-K. Lee, K. Onimura, H. Tsutsumi, and T. Oishi, J. Polym. Sci., Part A: Polym. Chem., 38, 4315 (2000).

11. Y. Chujo and T. Saegusa, Adv. Polym. Sci., 100, 11 (1992).

12. R. Tamaki and Y. Chujo, Chem. Mater., 11, 1719 (1999).

13. C. M. Brick, Y. Ouchi, Y. Chujo, and R. M. Laine, Macromolecules, 38, 4661 (2005).

14. T. Sanji, Y. Nakatsuka, and H. Sakurai, Polym. J., 37, 1 (2005).

15. M. S. Newman and M. Renoll, J. Am. Chem. Soc., 67, 1621 (1945). 